This document is the accepted manuscript version of the following article:

Piermattei, A., Lingua, E., Urbinati, C., \& Garbarino, M. (2016). Pinus nigra

anthropogenic treelines in the central Apennines show common pattern of tree recruitment. European Journal of Forest Research, 135(6), 1119-1130.

https://doi .org/10.1007/s10342-016-0999-y

\title{
Pinus nigra anthropogenic treelines in the central Apennines show common pattern of tree recruitment
}

Alma Piermattei ${ }^{1,3}$, Emanuele Lingua $^{2}$, Carlo Urbinati $^{1}$, Matteo Garbarino ${ }^{1 *}$

1. Department of Agricultural, Food and Environmental Sciences, Marche Polytechnic University, Via delle Brecce Bianche 10, I-60131, Ancona, AN, Italy

2. Department of Land, Environment, Agriculture and Forestry, University of Padova, Viale dell’Università 16, I-35020, Legnaro, PD, Italy

3. Swiss Federal Research Institute WSL, Zürcherstrasse 111, CH-8903 Birmensdorf, Switzerland

* Correspondence: Matteo Garbarino, Department of Agricultural, Food and Environmental

Sciences Marche Polytechnic University, Via delle Brecce Bianche 10, I-60131, Ancona, Italy

Tel.: +39 071-2204599

E-mail: m.garbarino@univpm.it

\section{Acknowledgements}

This research was partially financed by the Marche Polytechnic University through the project No. 4524/2009 "Spatiotemporal dynamics of forest vegetation and climate change in the Marche region". We wish to thank the following institutions and people for providing sampling authorization, logistic support, field and laboratory assistance: Monti Sibillini National Park, Gran Sasso-Monti della Laga National Park, Sirente-Velino Regional Park, and Bruno Petriccione, Francesco Renzaglia, Valeria Gallucci, Emidia Santini, Luca Bagnara, Matteo Giove, Andrea Cola, Simone Cingolani, Marco Altieri, Alessandro Vitali, Alan Crivellaro and Edoardo Piermattei. 


\begin{abstract}
Treeline position, structure and composition are shaped by natural and anthropogenic factors. At human disturbed treelines it is particularly difficult to disentangle the specific role of natural and anthropogenic drivers controlling tree recruitment dynamics following land abandonment. We tested for a possible common regeneration pattern of Pinus nigra Arn. at four upper treeline ecotones in the central Apennines (Italy). The sites were selected based on i) the occurrence of natural encroachment of $P$. nigra above $1600 \mathrm{~m}$ a.s.l., and ii) the mountain top elevation higher than $2000 \mathrm{~m}$ a.s.1. We assessed structure and spatio-temporal patterns of $P$. nigra advancing regeneration using point and surface pattern analyses. We mapped, measured and dated 845 trees sampled on a total surface area of 336 ha. $P$. nigra is the only tree species expanding at high altitude and features a scattered process that started 35-40 years ago, with a maximum recruitment frequency between 1995 and 2003. Pinus regeneration appeared over-dispersed along the slope at a scale range of 12-18 m, but saplings were clumped at short distances $(1 \mathrm{~m})$. We found spatial segregation between saplings and young trees at intermediate distances $(8-17 \mathrm{~m})$ and small patches of young trees distributed along the treeline ecotone. The spatial pattern of P. nigra encroachment in the central Apennines revealed a replicable model independent of treeline topography and local disturbance histories.
\end{abstract}

Keywords European black pine; pine regeneration; point pattern analysis; secondary succession; surface pattern analysis 


\section{Introduction}

Upper treelines are typical examples of margin vegetation and important ecological boundaries of dynamic landscapes (Bolli et al. 2007). Margins are of particular interest in vegetation science since they demonstrate a limit to the adaptation of a changing environment. Plant migrations are expected when these changes occur, however it is necessary to distinguish between climate and land use induced changes (Crawford 2008). The distinction between natural and cultural (human dominated) treelines should be very clear when assessing their structures and dynamics (Troll 1973; Miehe and Miehe 2000). Treelines can be classified as: i) climatic, ii) orographic/edaphic, and iii) anthropogenic depending on their main controlling factors (Holtmeier and Broll 2005). Natural constraints such as climate, soil and topography prevail on sites less disturbed by humans, whereas anthropogenic treelines develop under more severe human impacts (e.g. forest cover reduction or clearing, fire, cattle grazing) that alter site conditions (Holtmeier and Broll 2005). Climate and land use changes appear to be the two main and often synergic drivers that trigger tree establishment at upper treeline ecotones, causing either gap infilling or treeline upward shifts (Vittoz et al. 2008). A recent meta-analysis on 166 treeline sites around the world showed that $52 \%$ are advancing, $47 \%$ are stable and only $1 \%$ in recession (Harsch et al. 2009). The same authors use the treeline form as an indicator for controlling mechanisms and response to climate change. Diffuse and krummholz treelines indicate an advancement trend, whereas abrupt and island treelines appear to be more stable (Harsch et al. 2009; Harsch and Bader 2011). Climatic treelines, their position and advancement have been widely and extensively studied worldwide in the last decades (e.g. Troll 1973; Tranquillini 1979; Kullman 1998; Theurillat and Guisan 2001; Holtmeier and Broll 2005; Körner 2012). More recently, studies on anthropogenic treelines developed significantly, given that large parts of European upper treelines have been lowered by human induced disturbances. Their intensity and frequency decrease have caused widespread tree recruitment processes, with or without a treeline upward shift, on several mountain ranges (e.g. Carrer and Urbinati 2001; Dalen and Hofgaard 2005; Motta et al. 2006 ; Bolli et al. 2007; Rössler et al. 2008; Vittoz et al. 2008; Potthoff 2009).

In areas where man has had a significant impact on mountain ecosystems, especially at regional scale, land use change is an important driver of treeline ecotone dynamics in relation to shifting disturbance intensity (Gehrig-Fasel et al. 2007; Garbarino et al. 2013). In the Italian Alps the climatic upper treelines are limited to rocky, steeper and less accessible slopes and their current altitudes are largely influenced by anthropogenic and topographic factors (Leonelli et al. 2009). Structure and dynamics of treeline ecotones are strictly connected and influenced by species composition (Compostella and Caccianiga 2016). A transition from intensive to extensive grazing may favour tree recruitment during the initial stages, since grass species competition is reduced and soil is more exposed (Motta et al. 2006). Tree recruitment patterns then become largely dependent on the availability of microsites that provide suitable conditions for seedling 
establishment and growth. The microsite availability can decrease over time reducing the rate of tree encroachment (Bolli et al. 2007).

Treeline species composition is also a crucial aspect for tree recruitment in Mediterranean mountains such as the Apennines, the Dinaric Alps and the Balkans. Natural treelines were most likely formed by Pinus heldreichii (or P. leucodermis), P. peuce, and Picea abies which can still be found at some sites up to and above $2000 \mathrm{~m}$ a.s.l. (Barbero et al. 1995). P. mugo in the form of shrub is often located above treeline up to $2500-2600 \mathrm{~m}$ a.s.l., but today several anthropogenic treeline ecotones in the Apennines and less frequently in the Dinaric Mountains feature the dominance of broadleaved montane tree species such as Fagus sylvatica and locally Acer heldreichii. The reduction of cold-adapted needle-leaved taxa such as Pinus is probably due to a combination of past biogeographic and human induced events (Körner 2012). In the Apennines, a NW-SE 1000 km mountain range in Italy with several peaks higher than 2000 m a.s.l., high elevation forests since post-würmian times were first largely cleared for hunting, and later transformed into wood pastures or grasslands (Pedrotti 1969; Dibari et al. 2015). These ecotones, after previously severe pressure and increasing abandonment, are now marginal land and often included in protected areas. As in other European mountain regions, land abandonment has been a complex and non-linear process. In Italy, the most recent major change in land use occurred in the mid-20th century with the migration of mountain and rural populations downhill or to urban areas. In the Apennines this mass movement led to a dramatic decline in traditional grazing (Santilocchi and D'Ottavio 2005) and agricultural practices, but favoured diffused secondary ecological succession (Torta 2004; Caballero et al. 2009; Pelorosso et al. 2009). Between 1967 and 2007 permanent grassland cover in Italy decreased by 37\%, and the dairy cow population declined by 35\% in 1975-2007 with a negative peak after 1990 (Huyghe et al. 2014).

The Apennines treelines are on average located between 1600-1800 m a.s.l. and largely formed by European beech (Fagus sylvatica); Pinus species (P. mugo, P. nigra var. laricio, P. heldreichii) only prevail at a few sites, especially in central and southern sectors. The beech treelines can be defined as 'abrupt' and relatively stable due to the species intolerance to soil water deficit at higher altitude and to anthropic disturbances (Stanisci et al. 2000; Pezzi et al. 2008; Catorci et al. 2012). The pine treelines are considered 'diffuse' and more prone to altitude shifts. Pinus nigra treelines are an exception since this species is commonly found at lower elevation between 250-1600 m a.s.1. (Isajev et al. 2004). In the Balkans and Iberian Peninsula, they can reach $2000 \mathrm{~m}$ a.s.l. and form natural treelines (Richardson 2000). Due to its being a pioneer species $P$. nigra was planted extensively in the Apennines throughout the $20^{\text {th }}$ century on steep, rocky and overgrazed slopes between 1000-1600 m a.s.1., to reduce erosion and landslides. At these sites, we observed diffuse P. nigra regeneration, as the only encroaching tree species above the closed forest margin even above $2000 \mathrm{~m}$ a.s.l. (Piermattei et al. 2012; Piermattei et al. 2014). This expansion process at high altitude occurred due to a favourable coincidence of several facilitating factors such as grazing pressure decline, climate warming and seed supply from 
neighbouring pine plantations and also thanks to the ecological traits of this cold-adapted, drought resistant and competitive species (Richardson and Rejmanek 2004; Cousens et al. 2008). Previous papers described the progressive enlargement of the study area and focused on the chronological pattern, tree growth performance and climate sensitivity of P. nigra at high elevation in the central Apennines (Piermattei et al. 2012; Piermattei et al. 2014).

In this study, we compared spatial pattern and structure of Pinus regeneration at four anthropogenic treeline ecotones of the central Apennines exhibiting different topographic features and land use histories. Tree recruitment processes above the current treeline were studied at fine spatial scales in order to assess the influence of local environmental changes (Veblen 1992). We tested for a possible common spatial pattern suggesting the presence of a predictable underlying process in the central limestone Apennines. Our main hypotheses were: 1) P. nigra scattered encroachment at high elevation is a widespread process with a typical spatial pattern independent of microsite conditions; 2) trees of different age classes are spatially segregated due to intra-species competition; 3) density, tree size and age structure of Pinus regeneration is constrained by elevation. 


\section{Materials and methods}

\subsection{Study area and sampling design}

We sampled four upper treeline ecotones in the central Apennines (Italy) across the Marche (Mt. Vettore - VET) and Abruzzo (Mt. San Franco - SFR, Mt. Sirente - SIR, and Mt. Ocre - OCR) regions (Fig. 1). The four ecotones were selected by field visits and aerial photographs interpretation according to two requirements: presence of Pinus regeneration over $1600 \mathrm{~m}$ a.s.1., and a mountain top elevation higher than $2000 \mathrm{~m}$ a.s.l. For the purpose of this study we considered as forestline the upper limit of a closed canopy forest (either $F$. sylvatica natural forest or $P$. nigra plantation), and as treeline ecotone the area between the forestline and the encroached trees at the highest elevation reached. All study sites are included in different types of protected areas: VET is in the Sibillini National Park, SFR in the Gran Sasso-Monti della Laga National Park, SIR in the Sirente-Velino Regional Park, and OCR in the Monte Ocre-Acquazzese State Forest. All sites are on calcareous bedrock, and the peak elevation ranges from $2132 \mathrm{~m}$ a.s.l. at SFR to $2478 \mathrm{~m}$ a.s.l. at VET. The forestline elevation ranges from $1350 \mathrm{~m}$ a.s.l. at OCR to $1650 \mathrm{~m}$ a.s.l. at SIR and the mean slope from $32^{\circ}$ to $36^{\circ}$ at all sites, except for $\operatorname{SIR}\left(19^{\circ}\right)$ that features a gentler topography (Table 1). All sites share a temperate oceanic macrobioclimate (sensu Rivas-Martinez and Rivas-Saenz 2009) with recurrent droughts in July and August and precipitation peaks in autumn and early spring (Table 1). Snowfalls are more common and abundant in late winter (February and March), but snow permanence on the ground is limited and discontinuous (De Bellis et al. 2010).

The four sites share some general common land use traits but have different local histories (Table 2). Livestock grazing at high elevation usually from May to mid-October is a tradition, but is now significantly decreasing at all sites. These grasslands experienced different grazing pressure: sheep, cows and more recently horses have contributed to the pastoral histories of these sites. Local records are lacking but in general grazing pressure was high (Peroni et al. 2000) and sheep largely decreased at all sites in the last 20-40 years. More specifically, sheep decreased by $50 \%$ at VET over the last 40 years (Piermattei et al. 2012), and from 5000 to 3000 units in the1980-2000 period at SFR, in the Gran Sasso area (Coppinger et al. 1983; Rolando et al. 2001). Grazing pressure was the most important human induced disturbance during the 1950s at OCR, but there was a dramatic decline between 1954 and 1995 (Peroni et al. 2000). There is still extensive livestock grazing (cows and then horses) at SIR, due to its gentler topography of a karst plateau and less strict nature conservation constraints (Piermattei et al. 2014). Uncontrolled intensive grazing in the past caused widespread slope erosion processes that required extensive Pinus plantations in the studied region between the 1950s and 1970s. Their ages are respectively: 45 (SIR), 48 (SFR), 51 (OCR) and 63 (VET) years and their upper limit is the current forestline. Natural Pinus nigra forests were not found in the proximity of the study sites. 


\subsection{Data collection}

Between 2009 and 2013 we surveyed an overall treeline ecotone surface area of 336 ha. At VET and SFR all Pinus trees present from the forestline upwards were sampled. At SIR and OCR, due to the larger extension of the ecotone area, we sampled in a transect (length $1700 \mathrm{~m}$ and width $218 \mathrm{~m}$ at SIR; length $440 \mathrm{~m}$ and width $150 \mathrm{~m}$ at OCR) established along the maximum slope from $1600 \mathrm{~m}$ a.s.l. upwards. A total of 845 encroached $P$. nigra trees were mapped above the forestline with a Trimble GeoXT GPS receiver and their positions corrected with post-processing differential correction $(0.5-1 \mathrm{~m}$ estimated accuracy). Basal stem diameter, cambial age, total height and number of bearing cones were measured for each Pinus individual. Cambial age of all trees with a basal stem diameter $\geq 4 \mathrm{~cm}$ was determined after the extraction of one basal increment core. For smaller trees we used the number of internodes (terminal bud scars) as a tree age proxy. Percentage cover of microhabitat types (bare soil, herbs and shrubs) was also visually estimated on $1 \mathrm{~m}$ radius subplots centred on each Pinus individual position.

\subsection{Data analysis}

Treeline structure was described by computing classic stand structure attributes such as tree density and size (stem diameter and total height). The relationships between tree recruitment years, tree size and topography were analysed through linear regression analyses.

Point Pattern Analysis (PPA) methods were applied to assess Pinus tree spatial patterns within the study area and the association between saplings (age < 10 years) and young trees (age $>15$ years) at different spatial scales. Pinus regenerating trees were classified as saplings and young trees in order to obtain balanced classes of more than 100 individuals (Wiegand and Moloney 2014) within the narrow age interval $(<40$ years) of the observed process. The spatially explicit dataset used for the analyses comprised only 787 living trees (171 VET, 241 SFR, 193 SIR and 182 OCR), 226 saplings, 250 intermediate and 311 young trees. We used pair-correlation functions, both univariate $(g(r))$ and bivariate $\left(g_{12}(r)\right)$ (Stoyan and Stoyan 1994). As low between-site variability was found from the preliminary ordination analyses, supported by the similar overall univariate spatial pattern found in all sites, we conducted the spatial analyses considering the four sites as pseudo-replications to assess the global average spatial pattern of $P$. nigra treeline ecotone expansion in the central Apennines. The results from each site were thus combined in one average graphic function, using the 'combine replicates tool' included in the Programita software (Wiegand and Moloney 2004; Petritan et al. 2014). The univariate pattern of Pinus trees was contrasted against the heterogeneous Poisson null model to account for first-order effects. This null model differs from the complete spatial randomness (CSR) one in that a function $\lambda$ (x, y) varies with location ( $\mathrm{x}, \mathrm{y})$ but maintains the independence of the occurrence of any point in respect to any other (Wiegand and Moloney 2004). We computed the intensity function $\lambda$ non-parametrically, directly from the data, using the Epanechnikov 
kernel estimators (Wiegand and Moloney 2014). Only points of the same category of interest were considered. We used

a radius of $20 \mathrm{~m}$ for the moving window estimator, considering that the influence of small trees does not exceed this distance in our high elevation sites. For the bivariate analyses between saplings and young trees, we adopted the antecedent condition null model applying the heterogeneous Poisson to only one category (saplings) of trees, maintaining the other fixed (young trees) in order to assess if pioneer individuals act as attracting microsite for younger seedlings, accelerating the encroachment process. The $95 \%$ confidence intervals for both univariate and bivariate analyses were computed from 999 Monte Carlo simulations (Stoyan and Stoyan 1994; Wiegand and Moloney 2004) and the goodnessof-fit (GoF) test for null hypothesis was performed (Diggle 2003). All analyses were done only for classes with more than 15 trees (Camarero et al. 2000), applying a $1 \mathrm{~m}$ lag distance and a maximum distance of $100 \mathrm{~m}$ with the grid-based software Programita (Wiegand and Moloney 2004), adopting a grid size of $1 \mathrm{~m}^{2}$ and a ring width of $5 \mathrm{~m}$.

In order to obtain a spatial localization of tree groups with similar age we used a local index of spatial association (LISA). In particular, the spatio-temporal patterns of tree recruitment were described with the Getis-Ord $G_{i} *(d)($ Getis and Ord 1992) index, using tree age as a quantitative variable. The LISA statistics can detect the local clustering around the individual location and add depth to inferences where a single measure of global association (e.g. Moran's I) can provide little meaningful information (Lamedica et al. 2011; Carrer et al. 2013). Based on previous PPA results, we selected two distance classes $(15$ and $50 \mathrm{~m}$ ) to assess fine- and coarse-scale structure potentially related to the processes at stand (Carrer et al. 2013; Petritan et al. 2014) and treeline scale. All local $G_{i} *(d)$ analyses were computed with the Rookcase Excel add-in (Sawada 1999). 


\section{Results}

\subsection{Treeline structure}

Pinus nigra recolonization in the central Apennines is a scattered process of isolated trees (average of 5-6 individuals per hectare). Tree size is small at all sites (mean height ranges between $119-211 \mathrm{~cm}$ and mean diameter between $7-13 \mathrm{~cm}$ ) with higher values at SIR (Table 3). The mean tree age ranged between 15 and 19 years, confirming the recent process at all sites. High standard deviation values show high within-site variability. Oldest trees age suggests that the first encroachment events started at least 35-40 years ago (1975-1980). Seeds were coming from neighbouring $P$. nigra plantations located at lower altitude. Recruitment frequencies are normally distributed and exhibit synchronized peaks within the period 1995-2003 at all sites, with a decrease in the last 5-10 years.

Altitude has a negative effect on regeneration density only at VET and SFR treelines but not on tree age. Trees of all ages were found at various elevations, revealing that the tree establishment occurred all along the available altitudinal gradient (Fig. 2). Maximum elevation reached by P. nigra is $2106 \mathrm{~m}$ a.s.1. but most trees are located at $1750-$ $1800 \mathrm{~m}$ a.s.l. at VET, SFR and OCR, and 1850-1900 m a.s.l at SIR. Tree height was positively associated with cambial age and negatively with elevation at all sites (Fig. 3). However, a decrease in tree height and diameter with increasing elevation was evident at VET, weak at SFR, and absent at OCR and SIR. $22.6 \%$ of surveyed trees were bearing cones, but only $13 \%$ had more than 20 cones/tree. Mean age of these trees was around 20 years, but some individuals reached maturity at 10 years old, whereas the average maturity age is 40 years (Farjon 2013).

Microhabitat type around the sampled trees varies at the four sites: grass cover was predominant at OCR (57\%) and VET (50\%), whereas bare soil (e.g. outcrops, rocky debris) dominated at SIR (69\%) and SFR (55\%). Presence of shrubs (mostly Juniperus communis) was less common, ranging from 4\% to $14 \%$ (SIR and VET).

\subsection{Spatial patterns}

The overall spatial pattern of P. nigra recruitment (univariate PPA under heterogeneous Poisson null-model) showed a significant (GoF: $p \leq 0.01)$ tendency towards over-dispersion between 12 and $18 \mathrm{~m}$ (Fig. 4). This average pattern is the result of the combined replicates procedure obtained from the random pattern observed at OCR, SFR and SIR, and from the weak departure from randomness observed at VET. Stratifying the dataset according to age groups, young trees showed no significant clustered distribution at any spatial scale and were within the expected distribution up to $40 \mathrm{~m}$ (Online Resource 1 and 2). According to the overall population structure, both age groups revealed a significant departure from randomness to regularity between 12-17 $\mathrm{m}$ and 13-17 $\mathrm{m}$ respectively (Online Resource 1). Considering the bivariate $g_{12}(\mathrm{r})$ under antecedent condition null model, negative spatial interaction (spatial segregation) existed between the two 
age classes at 8-17 m (Fig. 5, GoF: $p \leq 0.01$ ). The only exception was SFR, where we observed a random spatial relationship between saplings and young trees, without any departure from the confidence envelopes.

The local $G_{i}^{*}(d)$ statistic, rasterized on the treeline ecotone maps (Fig. 6), showed groups of even-aged trees older (hot spots) or younger (cold spots) than the mean age and described the spatiotemporal pattern of tree recruitment. Local $\mathrm{Gi}^{*}(d)$ statistic allowed the groups of trees with similar age to be identified and located along the studied slopes. A patchy surface pattern was common to all four sites, where encroaching trees established in different age cohorts in groups of variable size $(5-50 \mathrm{~m})$ randomly distributed along the treeline ecotone. The smaller $(5 \mathrm{~m})$ significant groups were present at SIR and the pattern was consistent at both 15 and $50 \mathrm{~m}$ spatial scales. 


\section{Discussion}

About 10 years ago, we first observed an upward expansion process of Pinus nigra at high altitude in several sites of the central Apennines: this is clearly a natural encroachment process with an anthropic origin. Pinus plantations forming the current forestline are important seed sources for supplying the observed process. However, at SIR and at a different site (ACU), not included in this analysis (Piermattei et al. 2012), the planted pines are highly scattered and very distant from the encroachment sites, demonstrating the long-distance dissemination provided by this tree species. Nonetheless given these conditions it is incorrect to define the ongoing process as a typical treeline upward shift driven mainly by natural constraints such as climate and topography.

This research highlighted a common pattern that underlies the tree recruitment process at all sites, regardless of some existing differences of local features such as topography and past land use. At VET and SFR ecotones the density of newly established trees decreased along the elevation gradient, but tree size not very much (height and diameter). A negative correlation between tree growth and elevation is well documented for other pine species such as $P$. uncinata in the Pyrenees (Camarero and Gutierrez 2004; Wiegand et al. 2006) and P. cembra in the Alps (Vittoz et al. 2008). A similar pattern could be expected for tree age and altitude but we did not observe it in our sites. The absence of a clear relationship between tree age and elevation was also observed in the Alps (Carrer et al. 2013) and Pyrenees (Camarero et al. 2000, Batllori et al. 2010). All this seems to prove that Pinus recruitment is not a progressive process along the slope, enhancing the role of the occurrence of safe sites that are favourable microsites for the establishment and growth of regeneration. In general, encroached trees are sparser at VET and OCR (2-3/ha), compared to SFR and SIR (6-7/ha), probably due to the prevailing grass cover where intraspecific competition between regenerating trees is higher (Table 3 ). For these reasons, the shrubs cover and the presence of rocky surfaces can be considered safe sites for the establishment of Pinus trees.

Despite the differences in topographic features and land use histories a common spatial pattern of Pinus regeneration seems to prevail at the four studied sites. This significant overall pattern appears clearly when combining together the observed pair-correlation functions of the four sites. There was no evidence of a clustered structure either for young trees or for the overall population (Fig. 4, 5b). These patterns were consistent in all the sites and suggest that the regeneration is sparsely distributed and not organized in even-aged tree cohorts. Significant negative spatial relationships between saplings and young trees were found in all sites, indicating segregation between the two age classes (Fig. 5). Spatial segregation between younger and older trees may be due to competition mechanisms and this pattern is commonly found in different forest ecosystems where regeneration mainly establishes within canopy gaps. This suggests that in our study sites, older trees do not provide a more favourable microhabitat for younger ones. Anyway, older trees were rare and may have affected younger individuals. A two-fold interpretation follows: the first one implies independence or 
competition rather than facilitation among trees, since site conditions are not extreme at these treeline ecotones. According

to the stress gradient hypothesis, facilitation is more evident in harsher environments (Callaway et al. 2002), as occurring in higher elevations treeline ecotones of the Alps (Lingua et al. 2008; Carrer et al. 2013). The second interpretation is that the pioneer trees, given their current size, are too small to significantly influence the surroundings and improve the microsite conditions for seed germination and seedling growth. The surface pattern analysis revealed that in all the study sites hot spots of older trees were distributed along the slope, without any significant influence of elevation (Fig. 6). Our results confirm that Pinus regeneration is only weakly clustered and seems not to be influenced by any particular linear gradient. The absence of such gradient makes it very difficult, at this stage of the process, to predict the further expansion of $P$. nigra regeneration within the studied sites. The common spatial pattern observed may be explained by the favourable contingent factors acting at regional scale, such as land use change and global warming that may overcome the local differences occurring in the studied ecotones.

Expansion of $P$. nigra at high altitude in the central Apennines is a spontaneous process occurring within an anthropogenic ecotone where the forestline pine plantations act as seed sources and pasture abandonment is the predisposing factor. The anthropogenic nature of these upslope secondary successions and the local relevance of land use changes hamper the natural treeline ecological theories being applied to these study cases. However, given the extended distribution of $P$. nigra (especially in plantations) in the central Apennines and it being a pioneer species, important landscape changes are likely to occur at higher elevation forest-grassland ecotones. Studies in southern France (Debain et al. 2005) showed how P. nigra, often considered an exogenous and invasive species, recruited more efficiently and grew faster than local $P$. sylvestris as grazing declined and a grassland community took over. Extensive grazing can favour the establishment of Pinus seedlings by reducing or eliminating competitors within the resident biota (Hulme 1996), whereas intensive grazing can hamper regeneration due to animal trampling or burrow formation. Herbivores may also indirectly influence Pinus recruitment by redistributing nutrients and affecting shrubs density, hence modifying the local microclimate. Indeed, Pinus needles contain terpenes, which make the foliage distasteful and not particularly attractive to livestock like cows, sheep and horses that are all selective feeders (Andrews et al. 2000). However, some pines (e.g. Pinus cembra and Pinus peuce) are grazed when the availability of grasses is limited. The presence of shrubs, acting as shelter against grazers, may facilitate the establishment of seedlings and influence the spatial distribution pattern (Callaway and Walker 1997).

P. nigra encroachment at high altitude is still an active process because the conditions for an expected further expansion of this species are assured by the increase in propagule supply. Seed sources have increased for two reasons: i) neighbouring artificial plantations remain the most significant supplier given that the mean age of these stands is greater than the $P$. nigra sexual maturity range (15-40 years) (Isajev et al. 2004); ii) several encroached trees (> 20\%) have also 
reached maturity and can act as seed suppliers modifying the future spatial pattern by new cohorts' formation. In this

regard, future research should focus on the potential role of these new seed sources as well as long-distance dispersal (LDD) by wind from the neighbouring artificial plantations. Wind direction, tree crown size, cone production and tree height (starting point for seed dispersal) could affect the colonization process (Richardson 2000). Nonetheless, other requirements need to be met to guarantee further recolonization at the treeline ecotone, such as the presence of suitable microsites and microclimate conditions for seed germination and seedling growth. Apart from topography, these factors are dependent on broader vegetation dynamics within a context of climate (especially extreme events) and land use changes. This research is a further contribution to the understanding of $P$. nigra dynamic behaviour at high altitude in the central Apennines, but further investigation with a multi-scale approach combining the appropriate methods at regional, local, population and individual levels is needed to implement a suitable modelling and to include the ongoing process as a real treeline advancement. 


\section{References}

Andrews J, Miller GR, Armstrong H (2000) The effects of mammalian herbivores on natural regeneration of upland, native woodland. Scottish Natural Heritage, Edinburgh

Barbero M, Loisel R, Quezél P, Richardson DM, Romane F (1998) Pines of the Mediterranean Basin. In: Richardson DM (ed) Ecology and biogeography of Pinus. Cambridge University Press, Cambridge, pp 153-170

Batllori E, Camarero JJ, Gutiérrez E (2010) Current regeneration patterns at the tree line in the Pyrenees indicate similar recruitment processes irrespective of the past disturbance regime. J Biogeogr 37:1938-1950

Bisci C, Cellini M, Farabollini P, Pittori C (1989) Le gradient thermique dans les Marches meridionales (Italie Centrale). Proc. Actes du Colloque de Pavia 2:27-33

Bolli JC., Rigling A, Bugmann H (2007). The influence of changes in climate and land-use on regeneration dynamics of Norway spruce at the treeline in the Swiss Alps. Silva Fennica 41(1):55-70

Caballero R, Fernandez-Gonzalez F, Badia RP, Molle G, Roggero PP, Bagella S, D’Ottavio P, Papanastasis VP, Fotiadis G, Sidiropoulou A, Ispikoudis I (2009). Grazing systems and biodiversity in Mediterranean areas: Spain, Italy and Greece. Pastos, 39:9-154

Callaway RM, Walker LR (1997) Competition and facilitation: a synthetic approach to interactions in plant communities. Ecology 78:1958-65

Callaway RM, Brooker RW, Choler P, Kikvidze Z, Lortie CJ, Michalet R, Cook BJ (2002) Positive interactions among alpine plants increase with stress. Nature 417:844-848

Camarero JJ, Gutiérrez E (2004) Pace and pattern of recent treeline dynamics: response of ecotones to climatic variability in the Spanish Pyrenees. Climatic Change 63:181-200

Camarero JJ, Gutiérrez E, Fortin MJ (2000) Spatial pattern of subalpine forest-alpine grassland ecotones in the Spanish Central Pyrenees. Forest Ecol Manag 134:1-16

Carrer M, Urbinati C (2001) Spatial analysis of structural and tree-ring related parameters in a timberline forest in the Italian Alps. Journal of Vegetation Science 12:643-652

Carrer M, Soraruf L, Lingua E (2013) Convergent space-time tree regeneration patterns along an elevation gradient at high altitude in the Alps. Forest Ecol Manag 304:1-9

Catorci A, Scapin W, Tardella FM, Vitanzi A (2012) Seedling survival and dynamics of upper timberline in Central Apennines. Pol J Ecol 60:79-94

Chiarugi A (1950) Le epoche glaciali dal punto di vista botanico. Accademia Nazionale dei Lincei 347:55-110

Compostella C, Caccianiga M (2016) A comparison between different treeline types shows contrasting responses to climate fluctuations. Plant Biosystems doi: 10.1080/11263504.1179695 
Coppinger R, Lorenz J, Glendinning J, Pinardi P (1983) Attentiveness of guarding dogs for reducing predation on domestic sheep. J Range Manage 36:275-279

Cousens R, Dytham C, Law R (2008) Dispersal in plants: a population perspective. Oxford University Press, Oxford

Crawford RMM (2008) Plants at the margin. Ecological limits and climate change. Cambridge University Press, Cambridge.

Dalen L, Hofgaard A (2005): Differential regional treeline dynamics in the Scandes Mountains. In: Arctic, Antarctic, and Alpine Research 37:284-296

Debain S, Curt T, Lepart J (2005) Indirect effects of grazing on the establishment of Pinus sylvestris and Pinus nigra seedlings in calcareous grasslands in relation to resource level. Ecoscience 12:192-201

De Bellis A, Pavan V, Levizzani V (2010) Climatologia e variabilità interannuale della neve sull'Appennino Emiliano Romagnolo. Quaderno Tecnico ARPA-SIMC n. 19

Dibari C, Argenti G, Catolfi F, Moriondo M, Staglianò N, Bindi M (2015) Pastoral suitabilty driven by future climate change along the Apennines. Italian Journal of Agronomy 10(659):109-116

Diggle PJ (2003) Statistical analysis of spatial point patterns. Edward Arnold, London

Farjon A (2013) Pinus nigra ssp. nigra. The IUCN Red List of Threatened Species 2013: e.T20453795A20453836. http://www.iucnredlist.org/details/20453795/0. Accessed 12 February 2016

Garbarino M, Lingua E, Weisberg PJ, Bottero A, Meloni F, Motta R (2013) Land-use history and topographic gradients as driving factors of subalpine Larix decidua forests. Landscape Ecol 28:805-817

Gehrig-Fasel J, Guisan A, Zimmermann NE (2007) Tree line shifts in the Swiss Alps: climate change or land abandonment? J Veg Sci 18:571-582

Getis A, Ord JK (1992) The analysis of spatial association by use of distance statistics. Geogr anal 24:189-206

Harsch MA, Hulme, PE, McGlone MS, Duncan RP (2009) Are treelines advancing? A global meta-analysis of treeline response to climate warming, Ecol Lett 12:1040-1049

Harsch MA, Bader MY (2011) Treeline form - a potential key to understanding treeline dynamics, Global Ecol Biogeogr 20:582-596

Harsch MA, McGlone MS, Wilmshurst JM (2014) Winter climate limits subantarctic low forest growth and establishment. PloS one 9: e93241 doi:10.1371/journal.pone.0093241

Holtmeier KF (2005) Mountain Timberlines. Ecology, Patchiness and Dynamics. Dordrecht, The Netherlands: Kluwer.

Holtmeier F, Broll G (2005) Sensitivity and response of northern hemisphere altitudinal and polar treelines to environmental change at landscape and local scales. Global Ecol Biogeogr 14:395-410

Hulme PE (1996) Herbivory, plant regeneration, and species coexistence. J Ecol 84:609-615 
Huyghe C, De Vliegher A, van Gils B, Peeters A (2014) Grasslands and herbivore production in Europe and effects of common policies. Editions Quae. Versailles

Isajev V, Fady B, Semerci H, Andonovski V (2004) EUFORGEN Technical Guidelines for genetic conservation and use for European black pine (Pinus nigra). International Plant Genetic Resources, Rome

Körner C (1998) A re-assessment of high elevation treeline positions and their explanation, Oecologia 115:445-459

Körner C (2012) Alpine Treelines. Functional Ecology of the Global High Elevation Tree Limits. Springer, Basel

Kullman L (1998): Tree-limits and montane forests in the Swedish Scandes: Sensitive biomonitors of climate change and variability, Ambio 27:312-321

Lamedica S, Lingua E, Popa I, Motta R, Carrer M (2011) Spatial structure in four Norway spruce stands with different management history in the Alps and Carpathians. Silva Fenn 45:865-873

Leonelli G, Pelfini M, Morra di Cella U (2009) Detecting climatic treelines in the Italian Alps: the influence of geomorphological factors and human impacts. Physical Geography 30: 338-352

Lingua E, Cherubini P, Nola P, Motta R (2008) Spatial structure along an altitudinal gradient in the Italian central Alps suggests competition and facilitation among coniferous species. J Veg Sci 19:425-436

Lowe JJ, Davite C, Moreno D, Maggi R (1994) Holocene pollen stratigraphy and human interference in the woodlands of the northern Apennines, Italy. The Holocene 4:153-164

Marchesoni V (1957) Storia climatico-forestale dell'Appennino umbro-marchigiano Ann Botanica 25:1-39

Miehe, G, Miehe, S (2000): Comparative high mountain research on the treeline ecotone under human impact, Erdkunde $54: 34-50$

Motta R, Morales M, Nola P (2006) Human land-use, forest dynamics and tree growth at the treeline in the Western Italian Alps. Ann For Sci 63:739-747

Pedrotti F (1969) Introduzione alla vegetazione dell'Appennino centrale. Mitt. ostalp-din pflanzensoz. 9:21-57

Pelorosso R, Leone A, Boccia L (2009) Land cover and land use change in the Italian central Apennines: a comparison of assessment methods. Appl Geogr 29:35-48

Peroni P, Ferri F, Avena GC (2000) Temporal and spatial changes in a mountainous area of central Italy. J Veg Sci $11: 505-514$

Petritan IC, Marzano R, Petritan AM, Lingua E (2014) Overstory succession in a mixed Quercus petraea-Fagus sylvatica old growth forest revealed through the spatial pattern of competition and mortality. Forest Ecol Manag 326:9-17

Pezzi G, Ferrari C, Corazza M (2008) The altitudinal limit of beech woods in the northern Apennines (Italy). Its spatial pattern and some thermal inferences. Folia Geobot 43:447-459 
Piermattei A, Renzaglia F, Urbinati C (2012) Recent expansion of Pinus nigra Arn. above the timberline in the central Apennines, Italy. Ann For Sci 69:509-517

Piermattei A, Garbarino M, Urbinati C (2014) Structural attributes, tree-ring growth and climate sensitivity of Pinus nigra Arn. at high altitude: common patterns of a possible treeline shift in the central Apennines (Italy). Dendrochronologia $32: 210-219$

Potthoff K (2009) Grazing history affects the tree-line ecotone: a case study from Hardanger, Western Norway. Fennia 187 (2):81-98

Richardson DM (2000) Ecology and Biogeography of Pinus. Cambridge University Press, Cambridge

Richardson DM, Rejmanek M (2004) Conifers as invasive aliens: a global survey and predictive framework. Divers Distrib 10:321-331

Rivas-Martinez S, Rivas-Saenz S (2009) Worldwide Bioclimatic Classification System, 1996-2015. Phytosociological Research Center, Spain. http://www.globalbioclimatics.org. Accessed 28 July 2015

Rössler O, Bräuning A, Löffler J (2008) Dynamics and driving forces of treeline fluctuation and regeneration in central Norway during the past decades. Erdkunde 62:117-128

Rolando A, Caldoni R, Sanctis A, Laiolo P (2001) Vigilance and neighbour distance in foraging flocks of red-billed choughs, Pyrrhocorax pyrrhocorax. J Zool 253:225-232

Santilocchi R, D’Ottavio P (2005) The evolution of cattle and sheep breeding systems in Central Italy over the past two centuries. In: Georgoudis A, Rosati A, Mosconi C (eds) Animal production and natural resources utilisation in the Mediterranean mountain areas. Wageningen Academic Pub, Wageningen, pp 15-18

Sawada M (1999) Rookcase: an Excel 97/2000 Visual Basic (VB) add-in for exploring global and local spatial autocorrelation. Bull Ecol Soc Am 80:231-234

Slatyer RO, Noble IR (1992) Dynamics of montane treelines. In: di Castri F, Hansen AJ (eds) Landscape Boundaries. Consequences for Biotic Diversity and Ecological Flows. Springer, New York, pp 346-359

Stanisci A, Lavieri D, Acosta A, Blasi C (2000) Structure and diversity trends at Fagus timberline in central Italy. Community Ecol 1:133-138

Stoyan D, Stoyan H (1994) Fractals, Random Shapes, and Point Fields: Methods of Geometrical Statistics. Wiley, Chichester

Theurillat JP, Guisan A (2001) Potential impacts of climate change on vegetation in the European Alps: A review. Clim Change 50:77-109 
Torta G (2004) Consequences of rural abandonment in a Northern Apennines landscape (Tuscany, Italy). In: Mazzoleni S, Di Pasquale G, Mulligan M, Di Martino P, Rego F (eds) Recent Dynamics of the Mediterranean Vegetation and Landscape. John Wiley \& Sons, Chichester, pp 157-165

Tranquillini W (1979) Physiological ecology of the alpine timberline. Ecological Series 31. Springer

Troll C (1973) The upper timberlines in different climatic zones. Arctic Alpine Res 5:3-18

Veblen TT (1992) Regeneration dynamics. In: Glenn-Lewin DC, Peet RK, Veblen TT (eds) Plant succession: Theory and prediction. Chapman \& Hall, London, pp 152-187

Vittoz P, Rulence B, Largey T, Freléchoux F (2008) Effects of climate and land-use change on the establishment and growth of cembran pine (Pinus cembra L.) over the altitudinal treeline ecotone in the Central Swiss Alps. Arct Antarct Alp Res 40:225-232

Wiegand T, Moloney KA (2004) Rings, circles, and null-models for point pattern analysis in ecology. Oikos 104:209229

Wiegand T, Moloney KA (2014) Handbook of Spatial Point-Pattern Analysis in Ecology. Chapman and Hall/CRC, Boca Ranton

Wiegand T, Camarero JJ, Rüger N, Gutiérrez E (2006) Abrupt population changes in treeline ecotones along smooth gradients. J Ecol 94:880-892 


\section{Tables}

Table 1. Physiographic and climatic features of the surveyed P. nigra treeline ecotone sites in the central Apennines. VET: Mt. Vettore, SFR: Mt. San Franco, SIR: Mt. Sirente, OCR: Mt. Ocre. 1961-1990 meteorological records are from the nearest weather stations: Mt. Monaco, 987 m a.s.l. (VET); Campotosto, $1430 \mathrm{~m}$ a.s.l. (SFR); L'Aquila, 685 m a.s.1. (SIR and OCR). The temperature and precipitation records of Campotosto and L'Aquila meteorological stations were provided by the Hydrographic and Mareographic Service of the Abruzzo Region, Italy. The temperature and precipitation records of Monte Monaco meteorological station were provided by the Centre of Ecology and Climatology - Geophysical Experimental Observatory at Macerata, Italy. The mean temperatures at the forestline elevation were extrapolated from the meteorological stations by using a temperature lapse rate of $0.47^{\circ} / 100 \mathrm{~m}$ (Bisci et al. 1989).

\begin{tabular}{|c|c|c|c|c|c|c|c|c|c|c|}
\hline Site & $\begin{array}{l}\text { Treeline } \\
\text { ecotone } \\
\text { surface } \\
\text { area } \\
\text { (ha) }\end{array}$ & $\begin{array}{l}\text { Surveyed } \\
\text { surface } \\
\text { area } \\
\text { (ha) }\end{array}$ & $\begin{array}{l}\text { Slope } \\
\text { aspect }\end{array}$ & $\begin{array}{l}\text { Mean } \\
\text { slope } \\
\text { angle } \\
\left({ }^{\circ}\right)\end{array}$ & $\begin{array}{l}\text { Forestline } \\
\text { elevation } \\
\text { (m a.s.l.) }\end{array}$ & $\begin{array}{l}\text { Mountain } \\
\text { top } \\
\text { elevation } \\
\text { (m a.s.l.) }\end{array}$ & $\begin{array}{l}\text { Latitude } \\
\left(\mathrm{N}^{\circ}\right)\end{array}$ & $\begin{array}{l}\text { Longitude } \\
\left(\mathrm{E}^{\circ}\right)\end{array}$ & $\begin{array}{l}\text { Annual } \\
\text { Precip. } \\
(\mathrm{mm})\end{array}$ & $\begin{array}{l}\text { Mean } \\
\text { Temp. } \\
\text { at } \\
\text { Forestline } \\
\text { elevation } \\
\left({ }^{\circ} \mathrm{C}\right)\end{array}$ \\
\hline VET & 181.3 & 87.6 & $\mathrm{~S}-\mathrm{SE}$ & $36^{\circ}$ & 1600 & 2478 & $42^{\circ} 81^{\prime}$ & $13^{\circ} 26^{\prime}$ & 1209.8 & 8.2 \\
\hline SFR & 53.5 & 35.6 & W - SW & $32^{\circ}$ & 1600 & 2132 & $42^{\circ} 45^{\prime}$ & $13^{\circ} 38^{\prime}$ & 994.0 & 7.0 \\
\hline SIR & 87.0 & 37.1 & W - SW & $19^{\circ}$ & 1650 & 2349 & $42^{\circ} 15^{\prime}$ & $13^{\circ} 60^{\prime}$ & 732.4 & 7.2 \\
\hline OCR & 14.0 & 6.0 & $N-N E$ & $33^{\circ}$ & 1350 & 2204 & $42^{\circ} 15^{\prime}$ & $13^{\circ} 27^{\prime}$ & 732.4 & 8.6 \\
\hline
\end{tabular}


Table 2. Anthropogenic disturbance histories at VET, SFR, SIR and OCR sites.

\begin{tabular}{|c|c|c|c|}
\hline Site & Grazing History & Grazing period & Forestline history \\
\hline VET & Sheep decreased by 50\% during 1970-2000 & May to mid-October & P. nigra plantation 63 yrs old \\
\hline SFR & Sheep decreased by $40 \%$ during $1980-2000$ & May to mid-October & P. nigra plantation 48 yrs old \\
\hline SIR & Grazing of cows and horses still active & May to mid-October & P. nigra plantation 45 yrs old \\
\hline OCR & Dramatic grazing decline during 1954-1995 & May to mid-October & P. nigra plantation $51 \mathrm{yrs}$ old \\
\hline
\end{tabular}


Table 3. Number and main structural variables of sampled Pinus nigra encroached trees at the four study sites. Diameter

1 (at root collar), height and age values are means \pm standard deviation (SD).

\begin{tabular}{llllll}
\hline Site & Living/Dead trees & $\begin{array}{l}\text { Density } \\
(\mathrm{n} / \mathrm{ha})\end{array}$ & $\begin{array}{l}\text { Diameter } \\
(\mathrm{cm})\end{array}$ & $\begin{array}{l}\text { Height } \\
(\mathrm{cm})\end{array}$ & $\begin{array}{l}\text { Age } \\
\text { (years })\end{array}$ \\
\hline VET & $177 / 4$ & 2 & $9 \pm 7.3$ & $150 \pm 138$ & $15 \pm 7$ \\
SFR & $241 / 13$ & 7 & $7 \pm 6.9$ & $119 \pm 117$ & $16 \pm 7$ \\
SIR & $194 / 16$ & 6 & $13 \pm 8.7$ & $211 \pm 157$ & $19 \pm 8$ \\
OCR & $182 / 18$ & 3 & $8 \pm 5.4$ & $133 \pm 97$ & $17 \pm 6$ \\
\hline
\end{tabular}




\section{Figure captions}

Fig. 1 Oblique ground-based photographs of four P. nigra treelines of the central Apennines: a) OCR, b) SFR, c) SIR, and d) VET.

Fig. 2 Relative frequency (a) and maximum age (b) of regenerating $P$. nigra along the elevation gradient, divided in 20 m elevation classes at four treeline ecotones (VET: Mt. Vettore, SFR: Mt. San Franco, SIR: Mt. Sirente, OCR: Mt. Ocre). Fig. 3 Scatterplot of tree height and age divided by elevation classes as indicated by grey scale colours and regression lines. All regressions were significant ( $p<0.001$ ), except for VET and SFR 1900-2000, and $R^{2}$ ranged from 0.28 (VET 1800-1900) and $0.85($ SIR > 2000).

Fig. 4 Univariate spatial pattern analysis of 537 Pinus trees in four central Apennine treelines adopting combined replicates. Bold line indicates the pair-correlation function $g(r)$ and the dotted line the expected value under the null model (heterogeneous Poisson); shaded areas encompass non-significant, i.e. random, distribution and represent points within the $2.5^{\text {th }}$ and $97.5^{\text {th }}$ percentile $g(r)$ values of the 999 Monte Carlo permutations. The inset graphs show the results of each site separately.

Fig. 5 Bivariate spatial pattern analysis of Pinus trees, considering two age classes (saplings < 10 years and young trees $>15$ years $)$, using the pair-correlation function $g_{12}(\mathrm{r})$. Black lines indicate the pair-correlation functions $g_{12}(\mathrm{r})$, the dotted line represents the expected value under the null model (antecedent condition and heterogeneous Poisson), and shaded areas encompass non-significant, i.e. random, distribution and represent points within the $2.5^{\text {th }}$ and $97.5^{\text {th }}$ percentile $g(r)$ values of the 999 simulations Monte Carlo permutations. The inset graphs show the results of each site separately.

Fig. 6 Interpolated (Natural Neighbour) and z-transformed local $G_{i}^{*}(d)$ values computed for tree age for $15 \mathrm{~m}$ and $50 \mathrm{~m}$ distance intervals. Red and blue areas are hot spots (i.e. groups of trees with age higher than the mean within the treeline) and cold spots (i.e. groups of trees with age lower than the mean within the treeline) respectively. Colour scale is proportional to the value of the local $G_{i}^{*}(d)$ index. Bold contour lines indicate significant $(p<0.005)$ clusters.

Online Resource 1 Univariate spatial pattern analysis of Pinus trees, considering two age classes (A- saplings < 10 years; B- young trees $>15$ years), using the pair-correlation function $g(r)$. Black lines indicate the pair-correlation functions $g(r)$ and the dotted line represents the expected value under the null model (heterogeneous Poisson); shaded areas encompass non-significant, i.e. random, distribution and represent points within the $2.5^{\text {th }}$ and $97.5^{\text {th }}$ percentile $g(r)$ values of the 999 simulations Monte Carlo permutations. The inset graphs show the results of each site separately.

Online Resource 2 Map of spatial distribution of Pinus individuals at four treelines of the central Apennines: VET, SIR, SFR and OCR. Size of points is proportional to the age class of trees. 


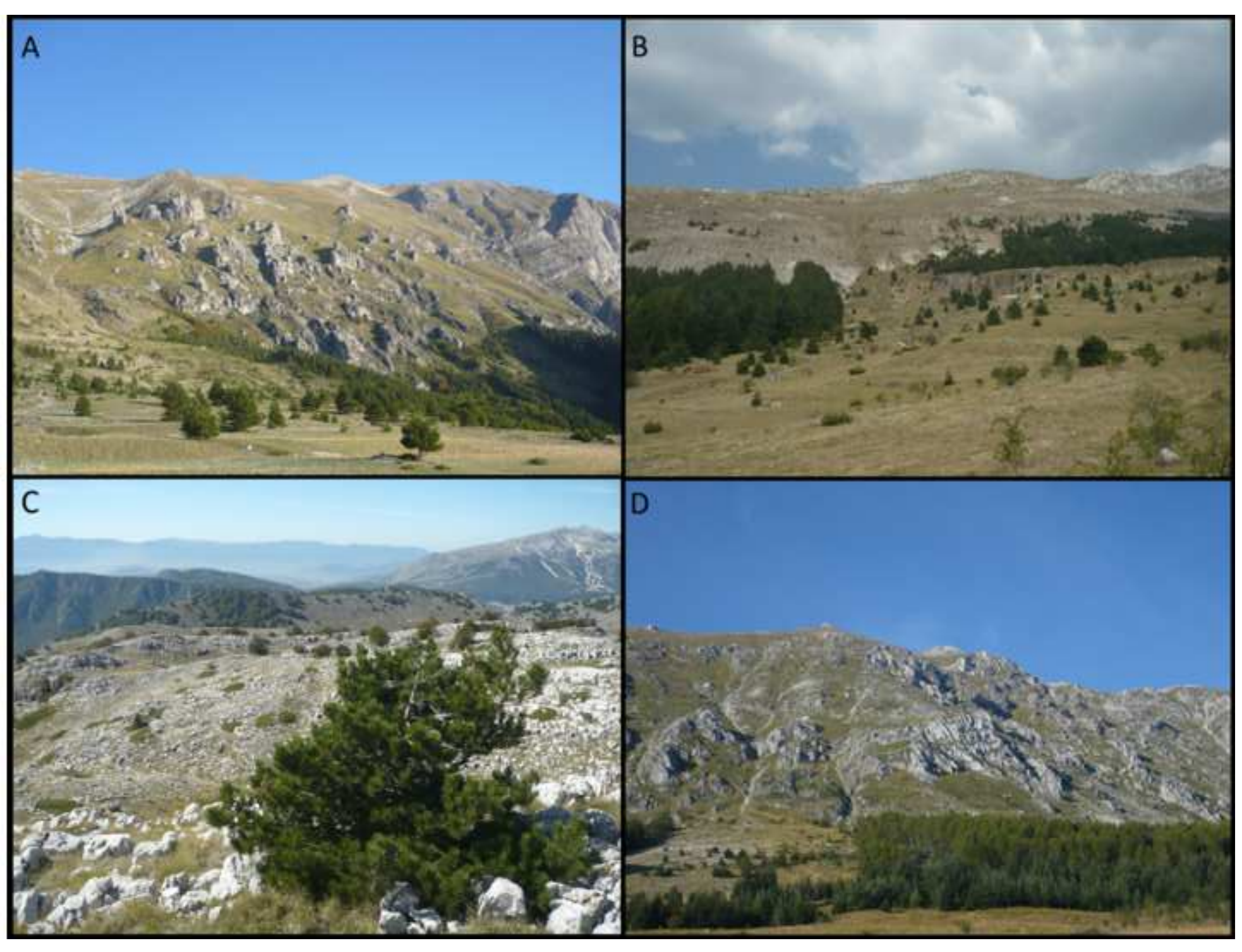 \\ Click here to download Figure Fig_1.tif $\underline{\underline{\underline{ }}}$}



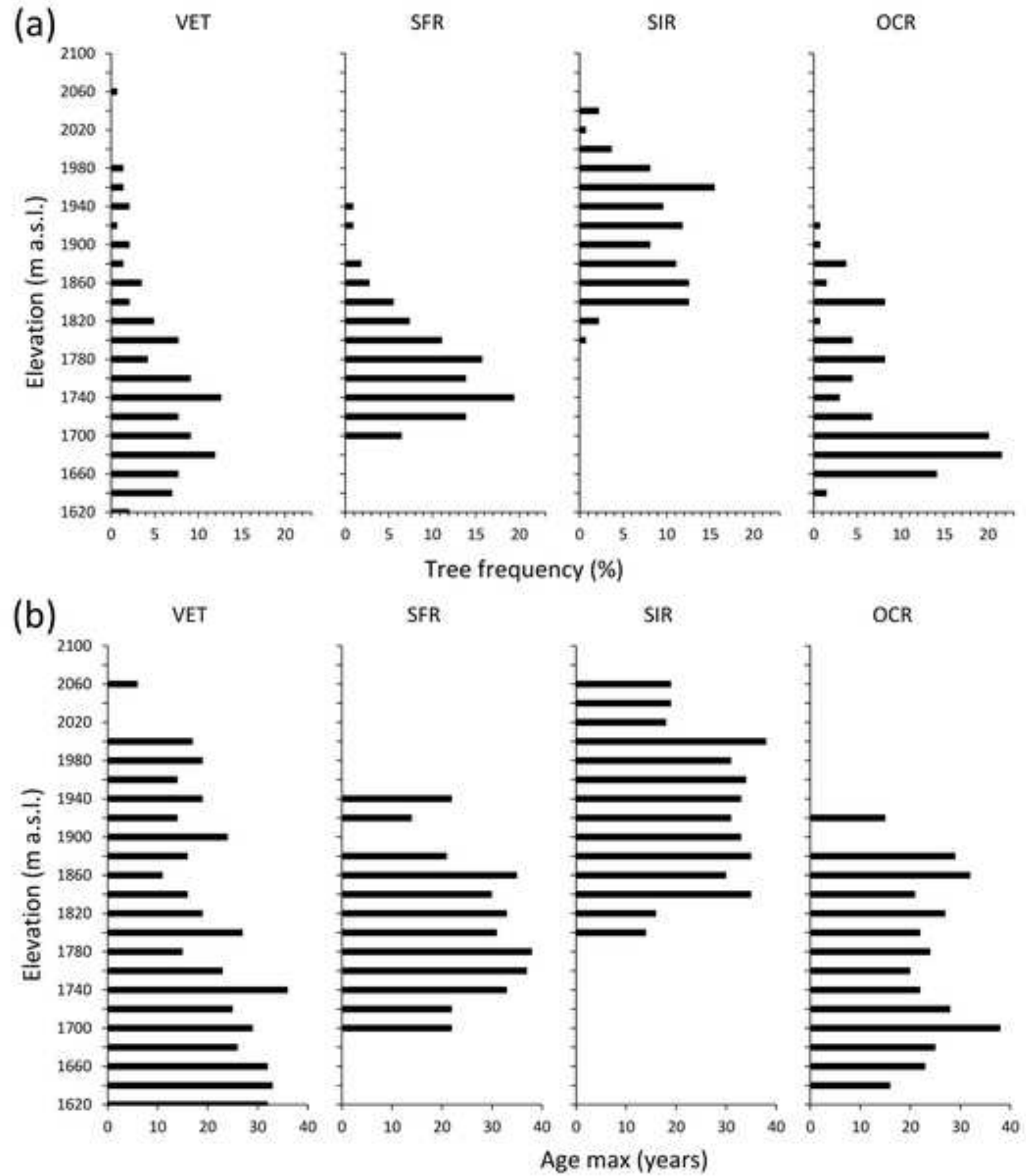

Age max (years) 

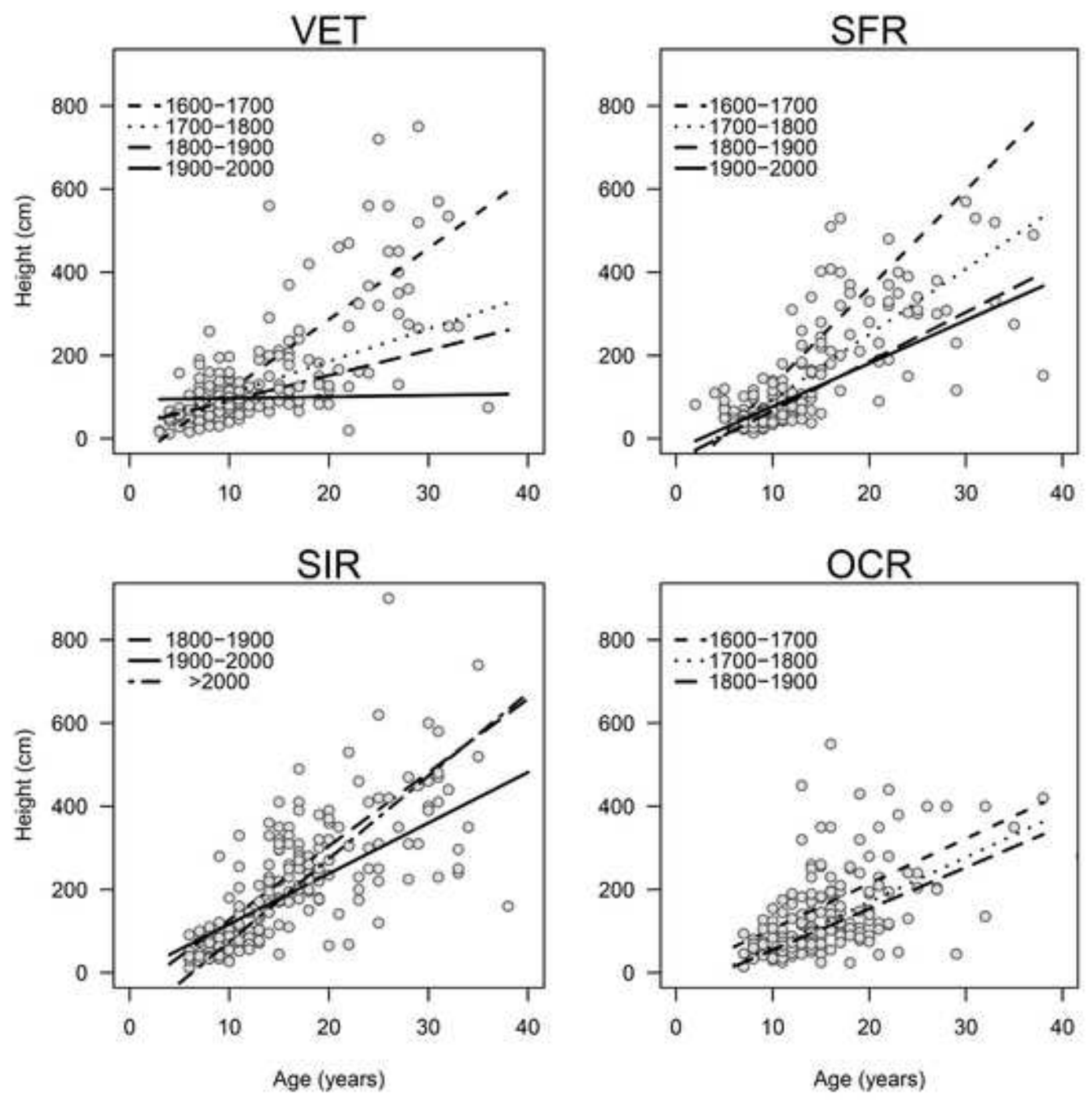


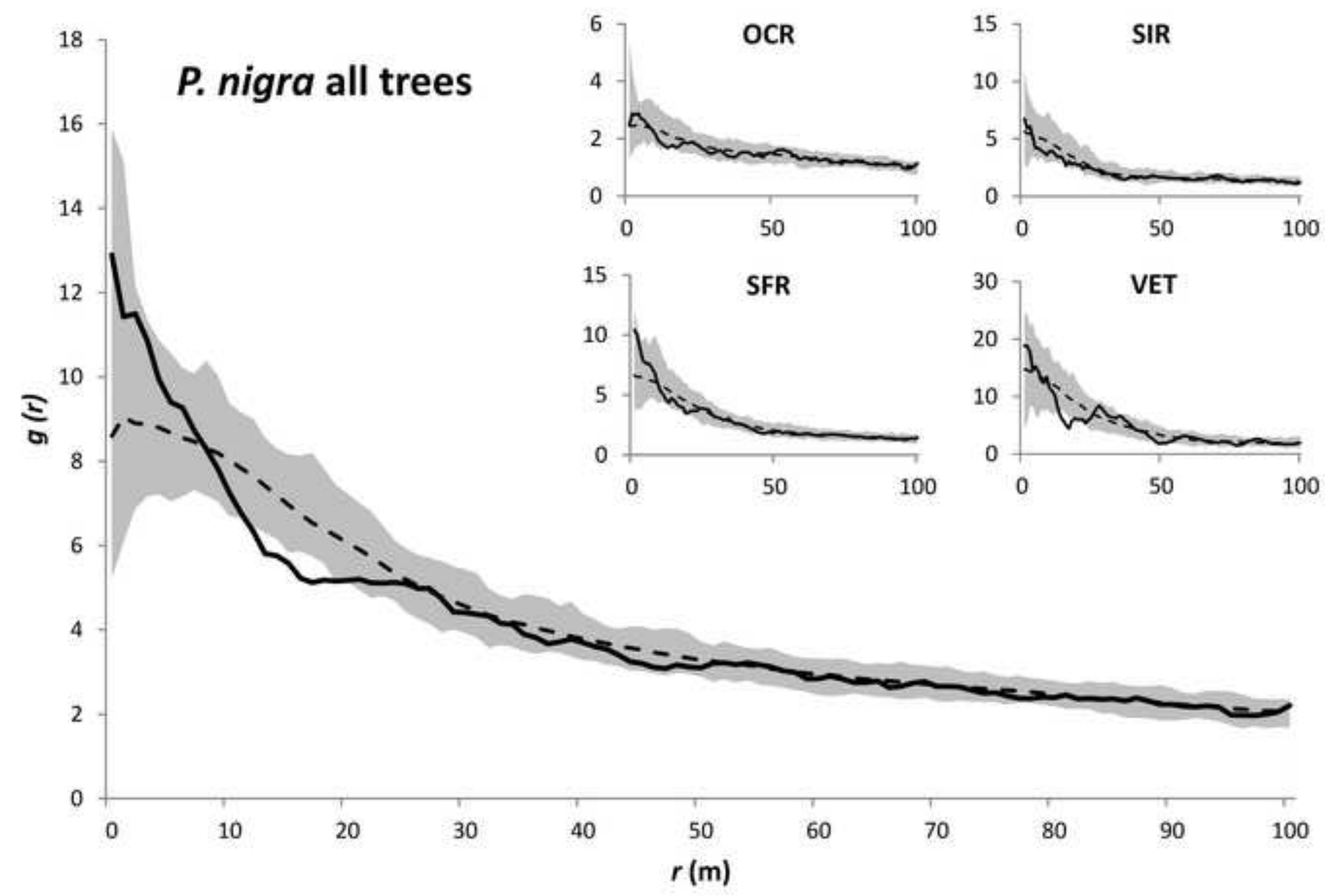




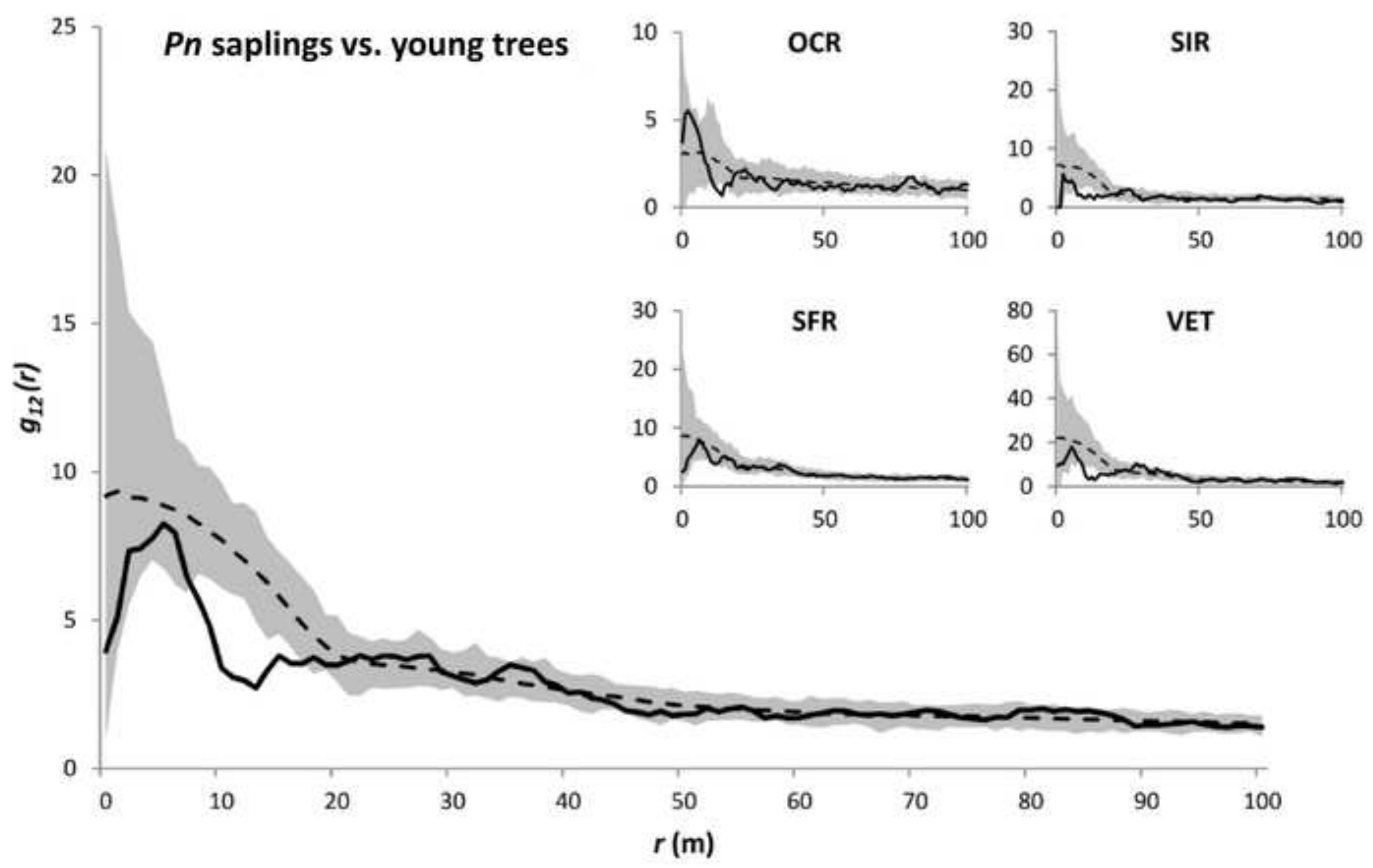




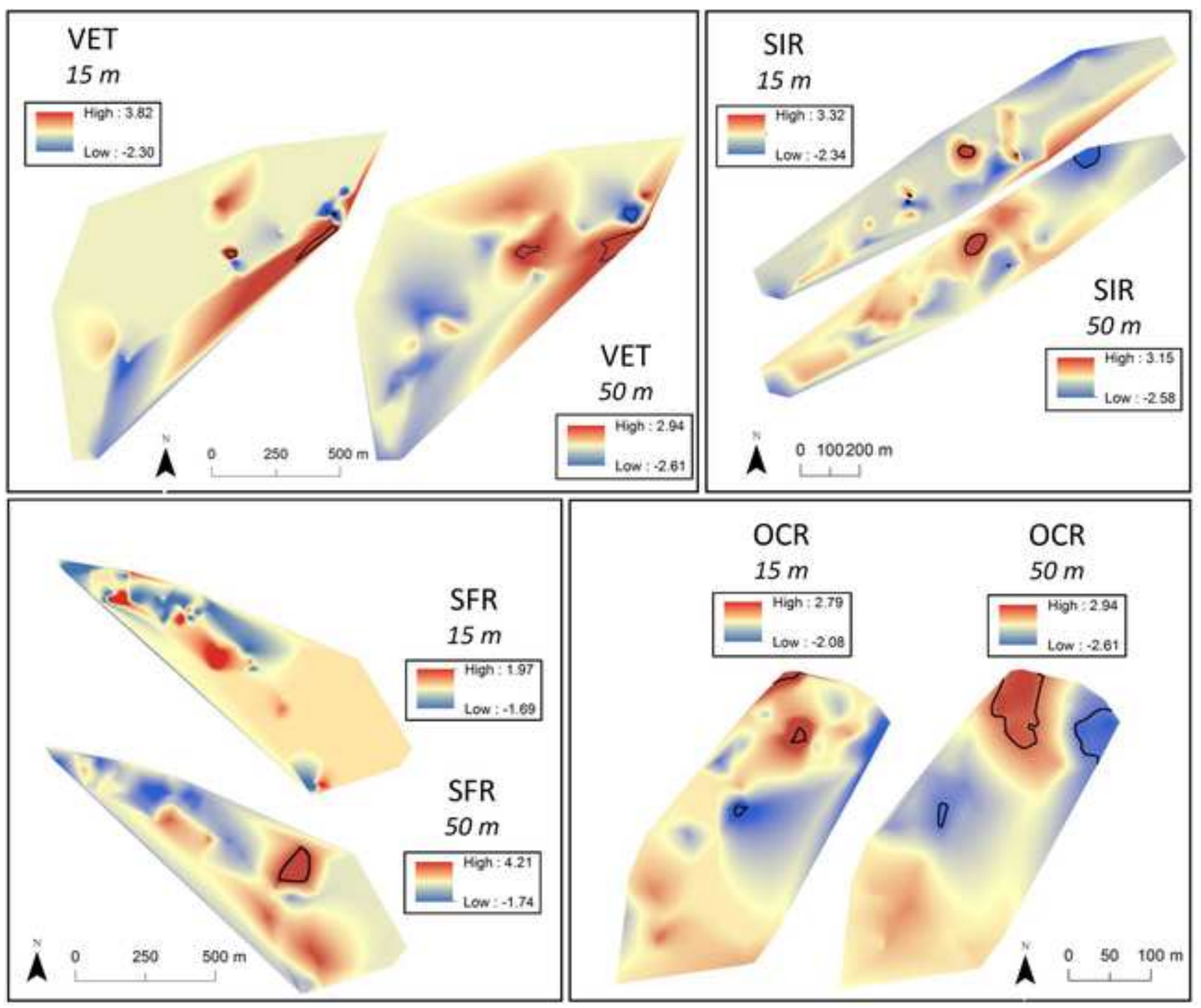


(a)
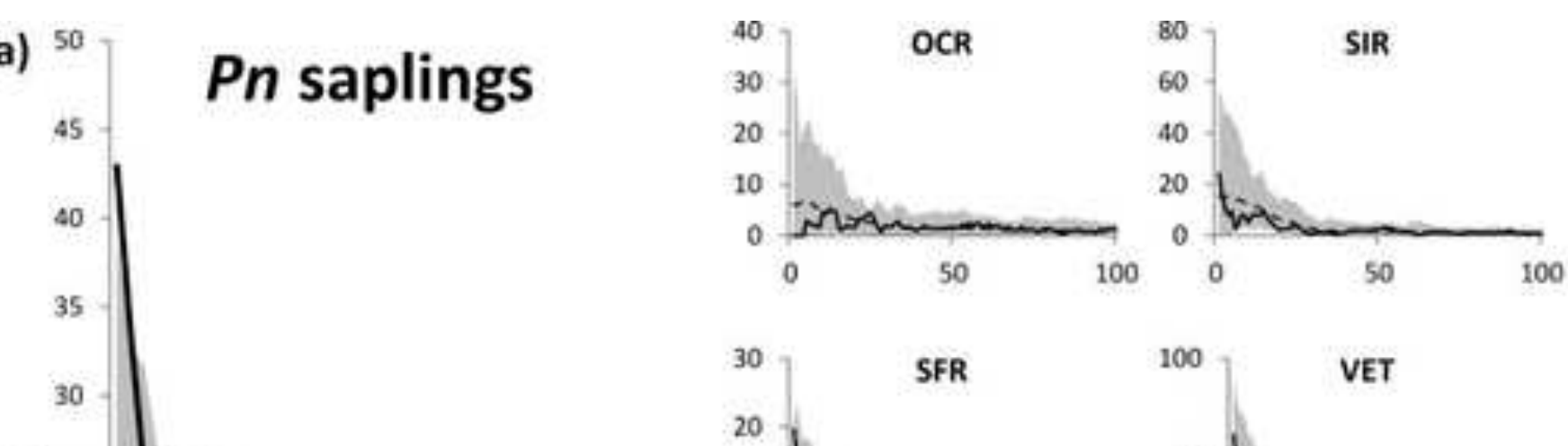

(b)
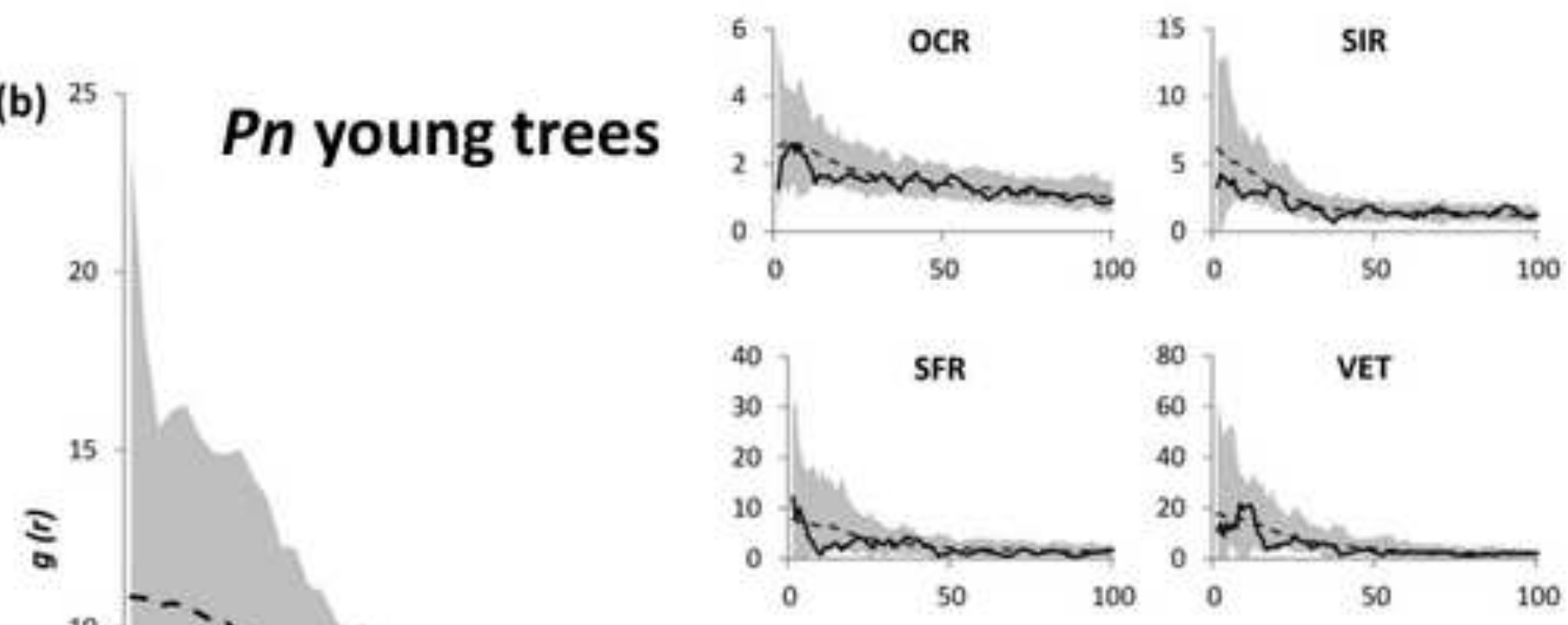

10
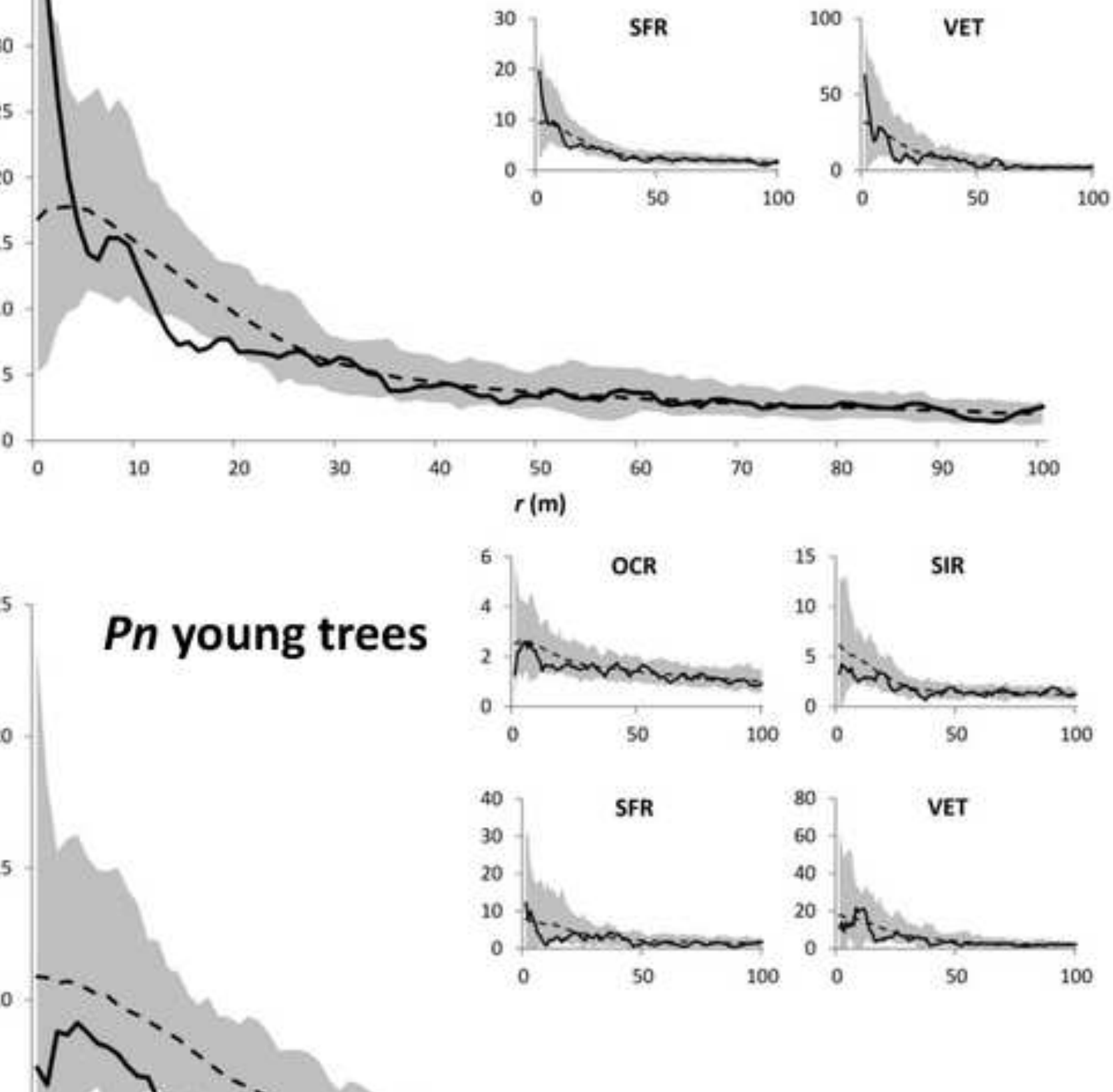

15
10
5
0
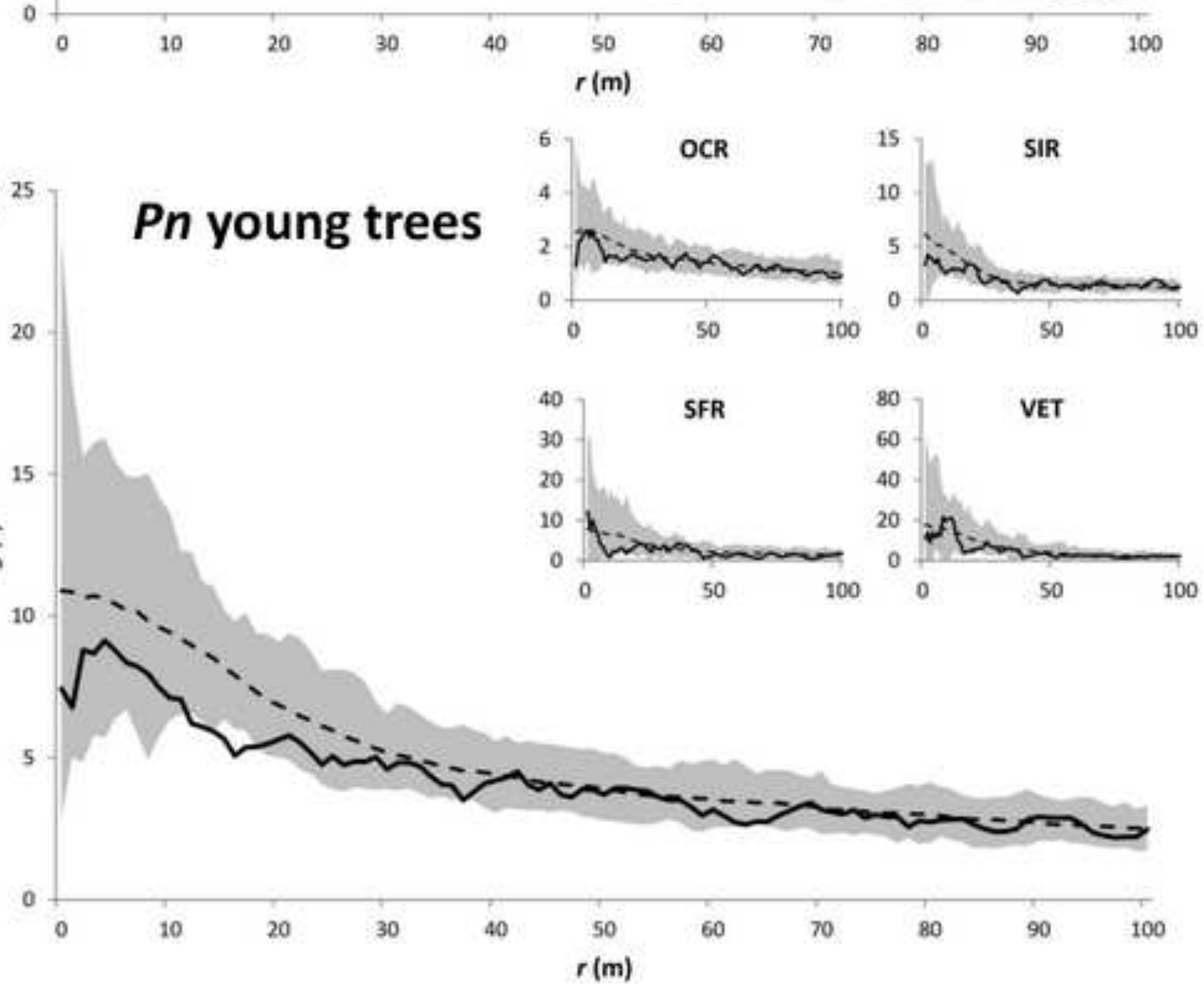

$\underline{\underline{ \pm}}$ 

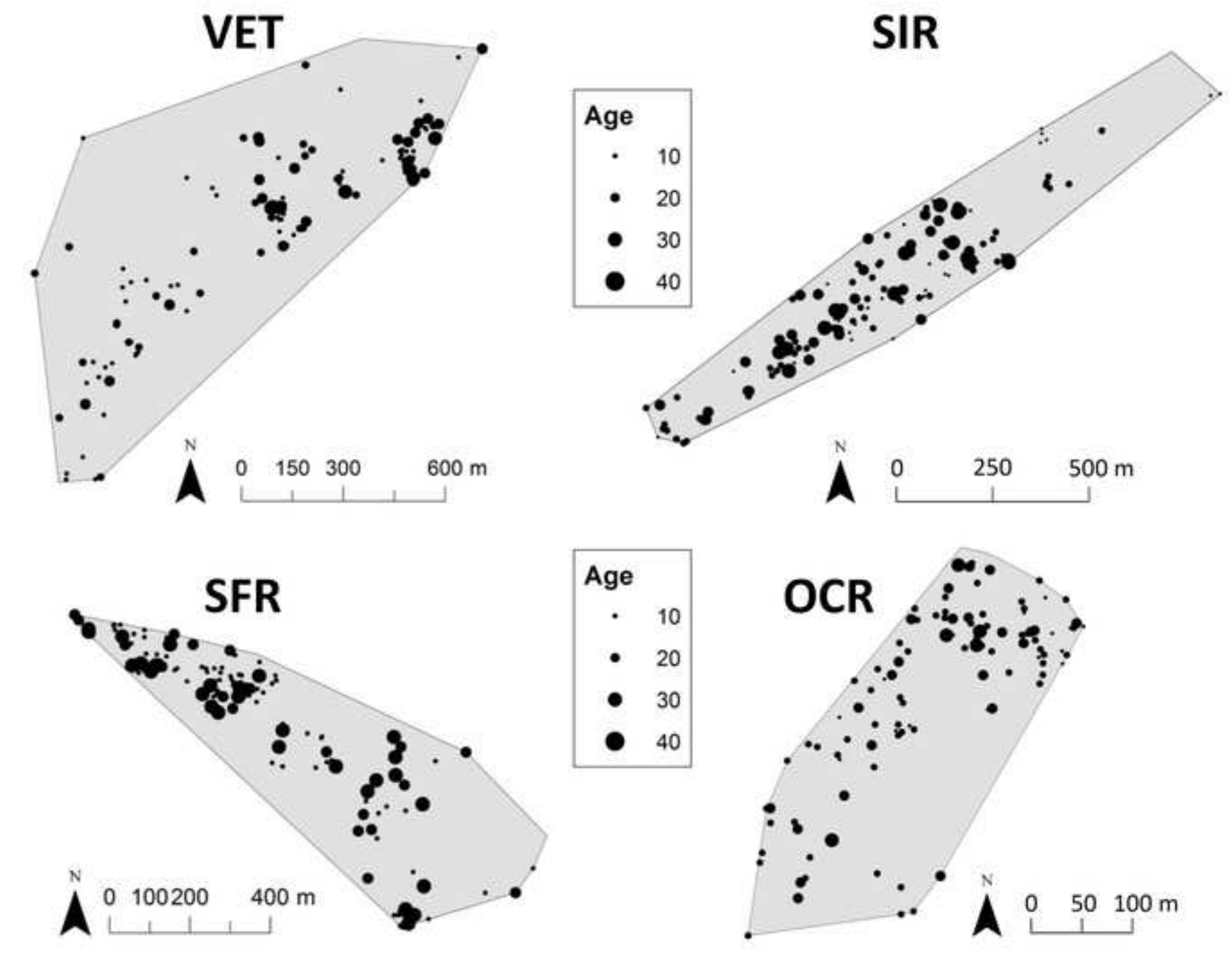